\title{
WAHDAT AL-ADYAN AND WAHDAT AL-SYUHUD SIRHINDI
}

\author{
Syamsul Qamar \\ Lecturer, Faculty of Tarbiyah dan Education, Alauddin State Islamic University \\ E-mail:syamsul.qamar@uin-alauddin.ac.id
}

\begin{abstract}
This writing is a study Wahdat al-Adyan and Wahdat al-Syuhud in in al-Sirhindi perspective. This is a literary research peered from various agreeable sources. The result shows that : a) The wahdat al-adyan of alHallaj and wahdāt al-syuhud of Sirhindi is a derivation of lā Ilāha Illallah; b) Wahdāt al-adyan tells that all religions are essentially identical and that they have one single purpose; worship to God; c) Wahdat al-syuhud throughout tauhid syuhudi tells an idea that all the matters came from The One. The idea, however, does not mean that everything is none.
\end{abstract}

Keywords: Wahdāt al-adyan; Wahdāt al-syuhud; al-Sirhindi

\section{INTRODUCTION}

Wahdāt al-adyan and Wahdāt al-syuhud are two terms derived from al-wahdāt (unity) in Tasawuf (sufism). Apart from that, there are also another concept known as Wahdāt al-wujud and wahdät al-ummah in tasawuf. According to Amin ${ }^{1}$, these concepts are sourced from the implementation of lä Iläha Illallah, the tawhid.

This tawhid has at least four different meanings. First, the acknowledge of the oneness of God; Second, the obedience of life following that concept; Third, the experience of being united and unified with God; Fourth, the theosophical construction about facts that comes from mysticism experience. ${ }^{2}$

From the sufism literature, the general term of the third meaning above, according to Ahmad Sirhindi ${ }^{3}$, is tauhid syuhudi. In a brief terminology, it means a perception (syuhud) of The One from the mystical experience, and ultimately unified with God. Whereas tauhid, as it mentioned in the fourth meaning, is often associated with tauhid wujudi or wahdat al-wujud. ${ }^{4}$

Tawhid is a single most important concept to all muslim. It is because tawhid constitute to a universal concept of how we suppose to see ourselves, others, and nature regard to its relations with divinity. Therefore, God is a "unique" entity, even beyond. Unattached with natural being that only limits Him. This is why understanding Him must also be unique, because He is The One above all else. Hence, monotheism or polytheism type of worship should be acceptable. Logically, however, the disticntion between them is the quantity; there is one divinity, and the other is more than one. ${ }^{5}$ This assumption, in which it is basically the nature of many beliefs tends to the monotheism concept. ${ }^{6}$ In the other words, everything is regarded as His creations and the signs of His mightiness.

66

${ }^{1}$ Ahmad Amin, Dzuhr al-Islam, juz II, (Kairo: Maktabah al-Nahdhah al-Mishriyyah, 1977), p. 65-

${ }^{2}$ Muhammad Abdul Haq Ansari, Sufism and Shari'ah: A Study of Syaikh Ahmad Srihindi's Effort Sufism, translated by Achmad Nashir Budiman entitled: Antara Sufisme dan Syariah, (Cet. I; Jakarta: CV. Rajawali, 1990), p. 147

${ }^{3}$ see ibid., p. 1-34

${ }^{4}$ Ibid., p. 147-148

${ }^{5}$ Ibn al-Arabi, Wahdāt al-Wujud dalam Perdebatan, (Jakarta: Paramadina, 1995), p. 74-86

${ }^{6}$ see Louis Massignon, The Passion of al-Hallaj: Mystic and Martyr of Islam, vol. III, Translated by Herbert Massan, (New Jersey: Princeton University Press, 1982), p. 221 
Sufism tells that the religions may vary, but they share similiar substance. It is because their source and purpose are the same, which is worshipping the Almighty.

This is what is known as the wahdāt al-adyān concept, or the unity of religions, introduced by al-Hallaj. ${ }^{7}$ Many pro and against this concept since it is first introduced and become a controversial topic among intellectuals, particularly from the sufism.

Therefore, this writing is trying to elaborate between these two terms; wahdāt aladyan and wahdät al-syuhud. The formulations of the problem are as follows:

1. What is wahdāt al-adyan?

2. And what is wahdāt al-syuhud?

\section{THE CONCEPT OF WAHDĀT $A L-A D Y A N$}

The concept of wahdāt al-adyan preceded by al-Hallaj is one of his teachings called hulul and Nur Muhammad theory. In Nur Muhammad theory, the wahdāt al-adyan has a direct relation, because Nur Muhammad is the path of all prophets. From that point, all the religions brought by the prophets are fundamentally identical, driven by al-Hallaj idea that all prophets are "emanated existence", just as being written on his hulul theory. He concluded that all religions comes and will eventually return to one entity, because all of which are emanated from it. al-Hallaj also concluded that all religions may vary, both in names and their forms, but they are essentially similar; worshipping The Almighty. ${ }^{8}$ They share one identical God, regardless of their names.

However, one astonishing idea from al-Hallaj is that there is no different essence between monotheism and polytheism. He said "Kufr (disbelief of God) and iman (faith) differ in names but not in essence, because both are indistinguishable."

His idea above underlined that people's religion basically is a God's will, not entirely preferred by the people themselves. Regarding to this case, Hick said that $99 \%$ of people choose their religion based on where they were born. A man being born in Thailand most likely to be a Budhist, and a man who is being born in Saudi Arabia would so much likely to be muslim. ${ }^{10}$ However, to us, one's religion is not a geographical determinaton. The urgent points are the place and people who gave them birth. In short, if their family is Christian, then they would probably to be a Christian. Also, if their family is Muslim, there is a high probability to them to be a Muslim either.

The concept of wahdat al-adyan stated that all religions are sourced from a single divine, and that religions are just its physical form. God is "exist" in every religions. ${ }^{11}$

Hazrat Inayat Khan ${ }^{12}$ expressed the same tone above, he mentioned that the variety of religions is just its shape. Like liquid, they have no solid shape, but they shape its

${ }^{7}$ See B. Lewis, et. all. (ed), The Encyclopedia of Islam, vol. III, (Leiden: E.J. Brill, 1971), p. 99. See Louis Massignon, op. cit., See Annemarie Schimmel, dalam Dimensi Mistik dalam Islam, translated by. Sapardi Djoko Damono, et. al., [Jakarta: Pustaka Firdaus, 1986), p. 66.Al-Hallaj was born in 858 M / 244 H. See Ahmad al-Santanawi, et.all., Dairat al-Ma'arif, vol. VIII, (t.k., t.p., t.t), p. 17. In his early age, he often went to the prominent sufi figures. And by 16 , he became a prominent sufi apprentice

${ }^{8}$ See Abd. al-Hakim Hassan, al-Tasawuf fiy al-Syi'ri al-'Arabi, (Cairo: al-Anjalu al-Mishriyyah, 1954), p. 375

${ }^{9}$ Ibid.,

${ }^{10}$ John Hick, An Interpretation of Religion, (New Haven and London: Yale University Press, 1989), p. $1-2$

${ }^{11}$ See Fathimah Usman, Wahdāt al-Adyān: Dialog Pluralismr Agama, (Vol. I; Yogyakarta: LKis, 2002), p. 14

${ }^{12}$ Hazrat Inayat Khan, The Unity of Religiouns Ideals, (London: Barrie and Jerkins, 1874), p. 15 
container. The liquid then turn into rivers, seas, lakes, streams or ponds. This concept corresponds to the religion itself. They are essentially similar, but different in many aspects.

Therefore, the al-Hallaj's wahdāt al-adyan does not mean to merge all religions. This is proven by his apprentice, Ibnu 'Arabi, by his idea; a universal religion, a mystical religion considers that God cannot be characterized, neither is limited to anything.

\section{THE CONCEPT OF WAHD $\overline{A T} A L-S Y U H U D$}

The teaching of wahdāt al-syuhud comes from Syekh Ahmad Sirhindi in his indepth learning distinguishing between tauhid rasuli and tauhid wujudi of Ibnu al-'Arabi. He then tried to arrange a philosophy based on the highest level of sufism about divinity transcendence referred to the Prophet's teachings. This philosophy is known as wahdāt al-syuhud or tauhid syuhudi; the experience of being united with God, but limited to a subjective perception (syuhudi) experience only. ${ }^{13}$

They figured out that there were two kinds of tauhid in main people, they are tauhid syuhudi and tauhid wujud. Tauhid syuhudi believes only in one Substance; the object perception of sufism is that there is nothing but The One. On the other hand, Tauhid wujudi believes that there is only Him, and the rest is void. Therefore, tauhid wujudi offers a knowledge framework ('ilm al-yaqin), while tauhid syuhudi offers a perception framework ('ain al-yaqin). ${ }^{14}$

Tauhid syuhudi is an essential part of sufism. A sufi will never feel fana and achieve the goal ('ain al-yaqin) without passing the maqam of the path. If the perception of The Almighty approves their sight, then they will disremember everything. In the other words, tauhid syuhudi is enough for fana' (forgetfulness), and create ikhlas, which is the highest level in sufism. Sirhindi said "About fana, we only need to perceive The One (tauhid syuhudi), so we can forget everything but Allah (ma siwa Allah)". Whereas tauhid wujudi is not part of the sufi path. It is because the percepction (ilm al-yaqin) can only be obtained without following the doctrine. ${ }^{15}$

Another ideas from Sirhindi is that God solely secluded from our world. He is a stand-alone entity. God is neither part of this world, nor His existence. God is Himself, excluded from our world, and both are different. ${ }^{16}$

This is resulting that the trueness comes from the substance of dualism (itsnainiyat). Sirhindi said that the highest level is dualism. The reason is that even if the world is apart from God (hama'ust), but it emerged from God (hama az-'ust). The existence of our wolrd is incomparable with His existence. This is because God existence is an absolute reality, while our world is an illusion (khayali) and not real (mauhum) ${ }^{17}$

Sirhindi believed that the existence of God is not identical to the existence of our world. It consequences that the existence of the world, to God, is not paradoxical with the "reality" that is mentioned earlier. There is only Him, The One. Our world is nothing but an image illusion, and this illusion obviously does not distort the oneness of God. ${ }^{18}$

\footnotetext{
${ }^{13}$ Lihat Muhammad Abd. Haq Ansari, loc. cit., h. 162

${ }^{14}$ Ibid, p. 308

${ }^{15}$ Ibid.,

${ }^{16}$ Ibid.,

${ }^{17}$ Ibid.,

${ }^{18}$ Ibid., p. 164
} 
The image of our world is not an existencce of an object, because an object is a solid matter in a space. It is unreal and only exist in perception (khis) and imagination (wahm), in the shadow dimension (kharij dzilli). Therefore, the existence of the image is the existence of a shadow (wujud dzilli) that is utterly different from the reality existence of an object. ${ }^{19}$

Sirhindi, through his non-existing concept ('adam), explains about the existence of unrealistically shadow world. In his philosophy, the non-existence ('adam) has a fully different connotation and meaningful. ${ }^{20}$

That is why the world, according to Sirhindi, is an essence instead of substance, not-existing, and unrealistic. It is only a shadow but equal in reality. It emerges from an absolut nothingness that eventually gains stability and permanence from the existence of God. It is a magical projection, an object that for a glance looks real, but in reality, it is nothing but an imagination.

\section{CONCLUSION}

The wahdàt al-adyan concept by al-Hallaj and the concept of wahdāt al-syuhud by Sirhindi is a derivation formulation from the tauhid, lā Ilāha Illallah.

The teaching of Wahdāt al-adyan tells that all religions are essentially similar and have the same purpose; worshipping the Almighty. They are different just in names.

Wahdat al-syuhud, through the concept of tauhid, teaches about a perception that all that exists is only God, but it does not mean that the other things does not.

\section{REFERENCE}

Amin, Ahmad, Dzuhr al-Islam, juz II, Kairo: Maktabah al-Nahdhah al-Mishriyyah, 1977.

Ansari, Muhammad Abdul Haq, Sufism and Shari'ah: A Study of Syaikh Ahmad Srihindi's Effort Sufism, diterjemahkan oleh Achmad Nashir Budiman dengan judul: Antara Sufisme dan Syariah, Ed. I; Jakarta: CV. Rajawali, 1990.

Al-'Arabi, Ibn, Fushūsh al-Hikām, diedit oleh Abū al-'Alī’ Afîfî, (two parts), Beirut: Dār al-Kitāb al-'Arabī, 1980.

Hassan, Abd. al-Hakim, al-Tasawuf fiy al-Syi'ri al-'Arabi, Kairo: al-Anjalu alMishriyyah, 1954.

Hick, John, An Interpretation of Religion, New Haven and London: Yale University Press, 1989.

Khan, Hazrat Inayat, The Unity of Religiouns Ideals, London: Barrie and Jerkins, 1874.

Lewis, B., et. all. (ed), The Encyclopedia of Islam, vol. III, Leiden: E.J. Brill, 1971.

\footnotetext{
${ }^{19}$ Ibid.,

${ }^{20} \mathrm{Ibid}$., p. 165
} 
Wahdat al-Adyan and Wahdat al-Syuhud Sirhindi

Massignon, Louis, The Passion of al-Hallaj: Mystic and Martyr of Islam, vol. III, Translated by Herbert Massan, New Jersey: Princeton University Press, 1982.

Usman, Fathimah, Wahdāt al-Adyān: Dialog Pluralismr Agama, Vol. I; Yogyakarta: LKiS, 2002. 